\title{
Maize hybrids contrasting for drought tolerance differ during the vegetative stage
}

\section{Híbridos de milho contrastantes para tolerância à seca diferem durante o estágio vegetativo}

\author{
Suerlani Aparecida Ferreira Moreira ${ }^{1 *}$; Pablo Fernando Santos Alves ${ }^{1}$; \\ Carlos Eduardo Corsato ${ }^{2}$; Alcinei Mistico Azevedo ${ }^{3}$
}

\section{Highlights:}

Multivariate analysis allows the study of the effect of water stress on maize roots.

The first two canonical variables explain $81.46 \%$ of the data variability.

Root volume and root dry biomass express the best correlations of canonical variables.

\begin{abstract}
Maize hybrids contrasting for drought tolerance differ during the vegetative stage. Drought is the main constraint on maize production in developing nations. Differences during development between genetic materials of maize grown under water restriction suggest that the plant can be improved with a view to its adaptation. In maize, sensitivity to water stress can occur at any stage of its phenological development. However, few studies report its effects on the vegetative phase of the cycle. On this basis, this study was conducted to examine how shoot and root-system indices are expressed in cultivation under water deficit as well as determine which indicators best explain the difference between hybrids in the evaluated water regimes. Commercial seeds of hybrids BR1055 and DKB-390 (drought-tolerant) and BRS1010 (drought-sensitive) were germinated in PVC tubes $(1.0 \mathrm{~m} \times 0.1 \mathrm{~m})$ in a randomized complete block design, in a $3 \times 2$ factorial arrangement. The experiment was developed in a greenhouse where two water regimes were tested: no water stress and with water stress from the VE stage. The soil consisted of quartz sand mixed with a commercial fertilizer. Stem and root traits were evaluated up to the V5 growth stage. Relative chlorophyll content, leaf temperature, stem length, phenology, shoot dry biomass, root length, root dry biomass, root surface area, root volume and $\mathrm{D}_{95}$ were responsive to water deficit. The parameters that allowed the distinction between the hybrids in water the regimes were relative chlorophyll content, leaf temperature, phenology and average root diameter.
\end{abstract}

Key words: Multivariate analysis. Water. Zea mays L.

\footnotetext{
1 Discentes do Curso de Doutorado do Programa de Pós-graduação em Produção Vegetal no Semiárido, Departamento de Ciências Agrárias, Universidade Estadual de Montes Claros, UNIMONTES, Campus Janaúba, MG, Brasil. E-mail: suerlanifasi@gmail. com; pablofsa@rpd.ufmg.br

2 Prof., Curso de Doutorado do Programa de Pós-Graduação em Produção Vegetal no Semiárido, Departamento de Ciências Agrárias, UNIMONTES, Campus Janaúba, MG, Brasil. E-mail: carlos.corsato@unimontes.br

3 Prof. Dr., Instituto de Ciências Agrárias, Universidade Federal de Minas Gerais, UFMG, Montes Claros, MG, Brasil. E-mail: alcineimistico@ufmg.br

* Author for correspondence
} 


\section{Resumo}

Híbridos de milho contrastantes para tolerância à seca diferem durante o estágio vegetativo. A seca é o principal fator de restrição para a produção de milho nas nações em desenvolvimento. Diferenças durante o desenvolvimento entre materiais genéticos de milho cultivados sob restrição de água sugerem que a planta pode ser melhorada visando a sua adaptação. No milho a sensibilidade ao estresse hídrico pode ocorrer em qualquer estágio do seu desenvolvimento fenológico. Contudo, poucos estudos relatam seus efeitos na fase vegetativa do ciclo. Desse modo, esse estudo teve como objetivos verificar como indicadores de parte aérea e sistema radicular se expressam mediante o cultivo sob déficit de água, bem como verificar quais indicadores melhor explicam a diferença entre híbridos nos regimes hídricos avaliados. Semente comerciais dos híbridos BR1055 e DKB-390 (tolerantes à seca) e BRS1010 (sensível à seca) foram germinadas em tubos de PVC $(1,0 \mathrm{~m}$ x $0,1 \mathrm{~m})$ em delineamento em blocos completos em esquema fatorial $3 \times 2$. O ensaio foi realizado em casa de vegetação em dois regimes hídricos; sem estresse hídrico e com estresse hídrico a partir do estádio VE. O solo foi constituído de areia de quartzo misturada com um fertilizante comercial. As características do caule e da raiz foram avaliadas até o estádio de crescimento V5. O teor relativo de clorofila, a temperatura foliar, comprimento do caule, fenologia, biomassa seca da parte aérea, comprimento de raiz, biomassa seca de raiz, área de superfície radicular, volume de raiz e $\mathrm{D}_{95}$ foram responsivos ao déficit hídrico. Os parâmetros que permitiram a distinção entre os híbridos nos regimes hídricos foram o teor relativo de clorofila, temperatura foliar, fenologia e diâmetro médio da raiz.

Palavras-chave: Água. Análise multivariada. Zea mays L.

\section{Introduction}

Drought is an environmental stress that significantly reduces the yield of various crops worldwide, including maize, Zea mays L. (Iwuala, Odjegba, Umebese, Sharma, \& Alam, 2019). In Brazil, where maize crops are mostly cultivated without irrigation, the irregular rainfall associated with the high cost of implementing irrigation systems has increased the water deficit in consecutive harvests, constituting the main obstacle in the production of this cereal (Bergamaschi \& Matzenauer, 2014).

The use of maize genotypes tolerant to cultivation in areas prone to water deficits has been pointed out as a strategy to minimize the effects of drought (Cooper, Gho, Leafgren, Tang, \& Messina, 2014). Screening maize genotypes grown under restrictive water conditions is the initial step to identify and understand, at the different plant organization levels, the drought-coping strategies to be applied in the development of adapted genetic material (Mutava, Prasad, Tuinstra, Kofoid, \& Yu, 2011).

Most studies on drought in the maize crop examine the responses to water restriction from the reproductive phase of the crop cycle, analyzing its impact on grain yield and final biomass. These findings have provided an understanding of responses and made it possible to identify materials tolerant to water deficit after flowering (Lavinsky, Magalhães, Ávila, Diniz, \& Souza, 2015).

However, water deficiency in maize is known to possibly occur even before its reproduction and in more than one stage of development. Little research has been done on the responses of maize genotypes to water deficits in the vegetative phase, which is extremely important information, since Indian summers are common in the early stages of crop development in many producing regions. According to Kamoshita, Rodriguez, Yamauchi and Wade (2004), seedling vigor may allow the roots to deepen before or during the first occurrences of drought, ensuring water extraction and the maintenance of growth during events of water deficit. Understanding how maize responds to drought in its early stages of development is of great relevance in studies aimed at the production of maize genotypes for regions where drought occurs during the initial stage of crop development, ensuring its establishment. 
For the phenotyping of maize genotypes aiming at tolerance to water deficiency, aerial-organ indices have been considered. These include cuticle thickness, earliness and synchronism in the interval between male and female flowering, leaf chlorophyll content, leaf water potential, leaf temperature, staygreen, leaf area index and plant growth analysis, besides production components that are positively or negatively correlated with crop yield (Teixeira et al., 2010; Beiragi, Ebrahimi, Mostafavi, Golbashy, \& Khorasani, 2011; Adebo \& Olaoye, 2015).

Characteristics of the root system pertaining to the acquisition of water in situations of water deficit have also been investigated with a view to the development of drought-tolerant genotypes. Studies examining differences between genotypes for root traits in response to the water regime have already been conducted in maize. Such traits include root cortical aerenchyma concentration (Zhu, Brown, \& Lynch, 2010), number of seminal roots, nodalroot biomass and length (Burton, Brown, \& Lynch, 2013) and seminal-root growth angle (Lynch, 2013).

The hypothesis underpinning this study is that shoot and root-system indices of maize hybrids respond differently to water deficit in the initial stage of development. Therefore, the objectives of this study were: a) to determine whether the indices are responsive to water deficit; and b) identify the existence of groups of indices that best explain the difference between hybrids in the evaluated water regimes.

\section{Material and Methods}

\section{Plant material and experimental design}

The commercial maize hybrids with contrasting yields in terms of cultivation under water stress DKB 390 and BRS 1055, considered tolerant, and sensitive hybrid BRS1010 (Magalhães, Souza, \& Albuquerque, 2012) were evaluated for their response to water deficit in the vegetative stage of their cycle.
The experiment was conducted at the State University of Montes Claros (Unimontes), JanaúbaMG campus, located in the semi-arid region of Brazil, from July to September 2017, for three consecutive cycles whose implementation dates were spaced one week apart. In each cycle, the plants were grown in tubular containers under two water regimes (no water stress and water-stressed), totaling six treatments, in a randomized complete block design with four replicates in a $3 \times 2$ factorial arrangement:

$$
\mathrm{y}_{\mathrm{ijkl}}=\mu+\alpha_{\mathrm{i}}+\beta_{\mathrm{j}}+(\alpha \beta)_{\mathrm{ij}}+\mathrm{b}_{\mathrm{k}}+\mathrm{d}_{(\mathrm{ij}) \mathrm{k}}+\mathrm{e}_{(\mathrm{ij}) \mathrm{kl}},
$$

where:

$\mathrm{y}_{\mathrm{ijkl}}$ is the value observed in the plot that received hybrid $\mathrm{i}$ and irrigation $\mathrm{j}$ in block $\mathrm{k}$ and replicate $\mathrm{l}$;

$\mu$ is the overall mean;

$\alpha_{i}$ is the effect of level $\mathrm{i}$ of factor a (hybrid);

$\beta_{\mathrm{j}}$ is the effect of level $\mathrm{j}$ of factor $\mathrm{b}$ (water regime);

$(\alpha \beta)_{i j}$ is the interaction effect between level $i$ of factor a and level $\mathrm{j}$ of factor $b$;

$b_{k}$ is the effect of block $k$;

$d_{(i j) k}$ is the interaction effect between level $i$ of factor $\mathrm{A}$, level $\mathrm{j}$ of factor B and block $\mathrm{k}$;

$\mathrm{e}_{\mathrm{ijkl}}$ is the experimental error in the plot that received hybrid $\mathrm{i}$ and water regime $\mathrm{j}$ in block $\mathrm{k}$ and replicate 1 .

\section{Monitoring of water regime and crop management}

PVC tubes $(1.0 \mathrm{~m} \times 0.1 \mathrm{~m})$ were coated internally with transparent high-density polyethylene film, filled with quartz sand and capped at the bottom with a perforated cap.

At sowing, the tubes intended for the treatment without water stress were filled with water up to field capacity $(1.640 \mathrm{~L})$, whereas the tubes corresponding to the water-stressed treatment received $30 \%$ of this volume $(0.490 \mathrm{~L})$. Two seeds were planted in each tube at a depth of five centimeters. On the fourth day after planting, each tube received a solution 
composed of $2.6 \mathrm{~g}$ of organo-mineral fertilizer Bravo Agrolatino (composition per liter: $8.5 \mathrm{~g} \mathrm{~N}$; $8.5 \mathrm{mg} \mathrm{P}_{2} \mathrm{O}_{5} ; 8.5 \mathrm{mg} \mathrm{K}_{2} \mathrm{O} ; 0.5 \mathrm{mg} \mathrm{Fe} ; 0.5 \mathrm{mg} \mathrm{Mn}$; $0.5 \mathrm{mg} \mathrm{B} ; 0.2 \mathrm{mg} \mathrm{Cu} ; 1.00 \mathrm{mg} \mathrm{Zn}$; and $0.10 \mathrm{mg}$ Mo), diluted in $100 \mathrm{~mL}$ of water.

From fertilization to harvest, the plants under water stress did not receive any more water, whereas the treatment without stress was maintained under field capacity. The tubes were held in an upright position within an anti-aphid screen and covered on the sides with extruded polystyrene (Styrofoam) plates to minimize the incidence of radiation. To reduce evaporation on the exposed surface of the substrate, the top opening of each tube was covered with transparent polyethylene film where a small crack was made to expose the emerging shoot. Upon reaching the stage of emergence (VE), the plants were thinned, leaving one plant per experimental unit.

\section{Evaluated traits}

The phenological stages (PHN) of maize were identified by evaluating the emergence of the sheath-blade junction ("collar"), in accordance with Abendroth, Elmore, Boyer and Marlay (2011). The plants were harvested when they were at the V5 stage, when destructive assessments of shoots and root system were carried out.

Stem length (SL) was measured using a ruler, from the soil level to the base of the blade of the last fully developed leaf.

Leaf temperature (LT) and relative chlorophyll content (RCC) were measured on the same day, in the last fully expanded leaf. The relative chlorophyll content was determined in SPAD units, using a chlorophyll meter (SPAD 502, Minolta, Japan), considering the average of three readings taken in each plot. Leaf temperature was measured using a RayTemp 38 digital infrared thermometer (Sussex, UK).
The relative water content of the leaves (RWC) was determined by removing three leaf discs from the last fully developed leaf, as recommended by Weatherley (1950). Shoot dry biomass (SB) was obtained after drying the samples in a forced-air oven at $65^{\circ} \mathrm{C}$.

After the sand was carefully removed with running water, the root system was preserved in a $70 \%$ ethanol solution and stored under refrigeration until the day of the evaluation. The samples were analyzed by the WinRHIZO Pro 2007a system (Régent Instr. Inc.), which was coupled to a professional Epson XL 10000 scanner equipped with an additional light unit (TPU) (400-dpi definition), as described by Costa et al. (2002). Each sample was placed in an acrylic bowl $(20 \mathrm{~cm}$ wide $\times 30 \mathrm{~cm}$ long) containing distilled water and each fraction was evaluated separately for root length (RL), root surface area (RSA), average root diameter (ARD) and root volume (RV).

Once evaluated by the WinRHIZO system, the samples were oven-dried at a temperature of $65^{\circ} \mathrm{C}$ until reaching constant weight, to determine the root dry mass (RB; g plant ${ }^{-1}$ ) and calculate the root/shoot dry biomass ratio $(\mathrm{RB} / \mathrm{SB})$.

To determine the depth above which $95 \%$ of the roots were located $\left(D_{95}\right)$, the accumulated proportions of roots were calculated from their total length at the different depths of the PVC tube profile, following the methodology proposed by Schenk and Jackson (2002).

\section{Data analysis}

After the normality and homogeneity of variances were checked by the Shapiro Wilk and Bartlett test $(p<0.05)$, the data were subjected to univariate analysis of variance. When significant by the $\mathrm{F}$ test $(\mathrm{p} \leq 0.05)$, the data were decomposed by Tukey's test at the 5\% significance level. Multivariate analysis of variance (MANOVA) was also applied for the 
grouping of different plant responses, considering the entire set of shoot and root indices. For this step, the MANOVA function of the Stats package was used with Pillai's test at 5\% significance. After the absence of multicollinearity was confirmed, the data were subjected to analysis of canonical variables (CV) by the candisc package (Friendly \& Fox, 2017). All statistical analyses were performed using R software (R Core Team [R], 2016).

\section{Results and Discussion}

Shoot variables

There was an interaction effect between hybrids and water regimes for SL and PHN. Isolated effects of water regimes were observed for RCC, LT and SB and an isolated effect of hybrids was detected for SB (Table 1).

The plants under water stress showed a $145 \%$ increase (Table 1) in RCC in relation to the condition without water stress. This result corroborates those published by Fonseca and Magalhães (2017), who subjected the same hybrids to water stress, but in the pre-flowering phase. Magalhães et al. (2009), on the other hand, reported a decrease in RCC from 42.36 to 35.32 SPAD units, under water stress, in relation to the irrigated crop. There is controversy in the literature regarding $\mathrm{RCC}$ in response to the regime imposed on the crop: while some authors describe a decrease, others report increases under water deficit conditions, which can be interpreted as an adaptive response to the stressor agents. For those authors, increases in the SPAD index in a situation of water restriction possibly indicate the activation of a mechanism of protection of the photosynthetic apparatus and appears to be a direct implication of the very development of chloroplasts, through the increase in number of thylakoids, or even the increase in number of chloroplasts. According to Araus, Serret and Edmeades (2012), the chlorophyll content has been a widely used physiological parameter for the selection of drought-tolerant maize genotypes, with genotypes more tolerant to water deficits exhibiting better photosynthetic performance under restricted water availability.

The water-stressed plants showed a higher LT than those which were not subjected to water stress (Table 1). A similar result was reported by Liu et al. (2011), who stated that leaf temperature may reflect drought tolerance in maize under water restriction and the difference in leaf temperature can be considered an indicator of drought tolerance even in the early stages of crop development.

Hybrid BRS1055 showed the highest SL in the stress-free condition, while hybrid DKB390 showed the highest values for this variable in the water-stressed environment (Table 1). In a study led by Kappes, Carvalho, Yamashita and Silva (2009), maize had a 49.23 to $74.51 \%$ reduction in shoot length when subjected to water stress, but this reduction varied according to the genotype tested. In their experiment, hybrids BRS1010 and BRS1055 exhibited differences in SL between the water regimes, with higher values observed under no water stress. For these genotypes, therefore, water restriction influenced the reduction of plant height. Rufino et al. (2012) evaluated the performance of four maize genotypes grown under water deficit in the vegetative stage and observed a reduction in plant height. When subjected to water restriction, plants reduce their stomatal opening and growth, which results in decreased elongation of organs such as the stem (Bengough, McKenzie, Hallett, \& Valentine, 2011). 
Table 1

Analysis of variance for hybrid $(H)$, water regime $(W R)$ and their interactions $(W R * H)$ on shoot indices of maize grown under two water regimes. Janaúba - MG, Brazil, 2017

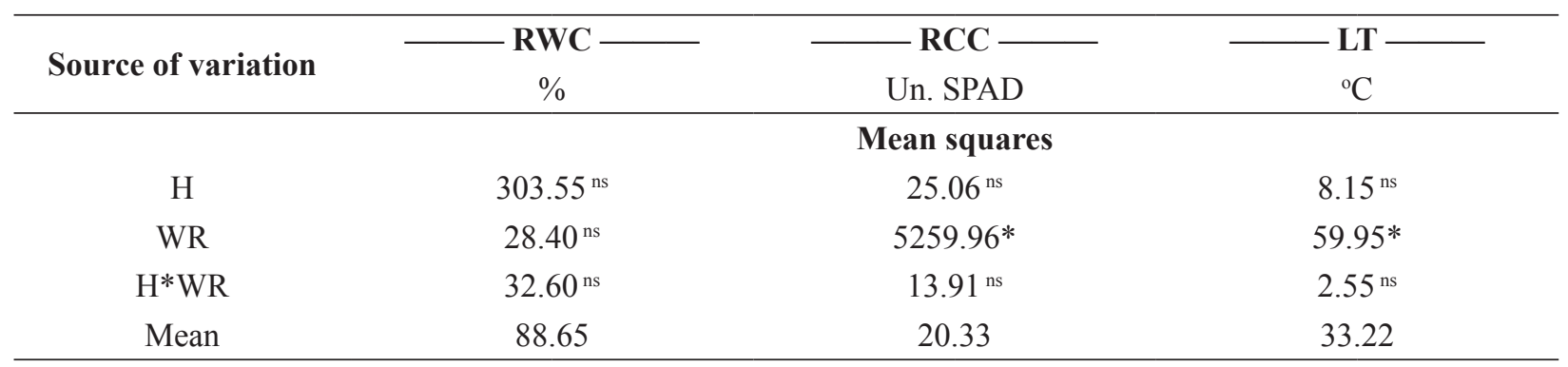

\begin{tabular}{|c|c|c|c|c|c|c|}
\hline \multirow{2}{*}{\multicolumn{7}{|c|}{ Treatment average }} \\
\hline & & & & & & \\
\hline BRS1010 & \multicolumn{2}{|c|}{$88.35 \mathrm{a}$} & \multicolumn{2}{|c|}{$20.52 \mathrm{a}$} & \multicolumn{2}{|c|}{$33.27 \mathrm{a}$} \\
\hline BRS1055 & \multicolumn{2}{|c|}{$85.25 \mathrm{a}$} & \multicolumn{2}{|c|}{$19.22 \mathrm{a}$} & \multicolumn{2}{|c|}{$32.62 \mathrm{a}$} \\
\hline DKB390 & \multicolumn{2}{|c|}{$93.34 \mathrm{a}$} & \multicolumn{2}{|c|}{$21.24 \mathrm{a}$} & \multicolumn{2}{|c|}{$33.78 \mathrm{a}$} \\
\hline \multicolumn{7}{|l|}{ WR } \\
\hline NWS & \multicolumn{2}{|c|}{$89.28 \mathrm{a}$} & \multicolumn{2}{|c|}{$11.78 \mathrm{~b}$} & \multicolumn{2}{|c|}{$32.31 \mathrm{~b}$} \\
\hline WS & \multicolumn{2}{|c|}{$88.02 \mathrm{a}$} & \multicolumn{2}{|c|}{$28.88 \mathrm{a}$} & \multicolumn{2}{|c|}{$34.13 \mathrm{a}$} \\
\hline \multicolumn{7}{|l|}{$\mathbf{R}^{*} \mathbf{H}$} \\
\hline & NWS & WS & NWS & WS & NWS & WS \\
\hline BRS1010 & $89.95 \mathrm{aA}$ & $86.76 \mathrm{aA}$ & $12.05 \mathrm{aB}$ & $28.99 \mathrm{aA}$ & $32.20 \mathrm{aB}$ & $34.41 \mathrm{aA}$ \\
\hline BRS1055 & $84.58 \mathrm{aA}$ & $85.91 \mathrm{aA}$ & $9.88 \mathrm{aB}$ & $28.57 \mathrm{aA}$ & $32.08 \mathrm{aB}$ & $33.15 \mathrm{aA}$ \\
\hline DKB390 & $93.30 \mathrm{aA}$ & $91.39 \mathrm{aA}$ & $13.41 \mathrm{aB}$ & $29.07 \mathrm{aA}$ & $32.65 \mathrm{aB}$ & $34.91 \mathrm{aA}$ \\
\hline \multirow{3}{*}{ Source of variation } & \multirow{2}{*}{\multicolumn{2}{|c|}{$\begin{array}{c}\mathbf{S L}- \\
\mathrm{cm}\end{array}$}} & \multirow{2}{*}{\multicolumn{2}{|c|}{$\begin{array}{c}\text { PHN }- \\
\text { days to V5 }\end{array}$}} & \multicolumn{2}{|c|}{$-\mathrm{SB}-$} \\
\hline & & & & & & \\
\hline & \multicolumn{6}{|c|}{ Mean squares } \\
\hline $\mathrm{H}$ & \multicolumn{2}{|c|}{$3.45^{\mathrm{ns}}$} & \multicolumn{2}{|c|}{$0.68^{\mathrm{ns}}$} & \multicolumn{2}{|c|}{$0.06^{*}$} \\
\hline WR & \multicolumn{2}{|c|}{$40.80^{*}$} & \multicolumn{2}{|c|}{$10.12 *$} & & \\
\hline $\mathrm{H}^{*} \mathrm{WR}$ & & & & & & \\
\hline Mean & & & & & & \\
\hline & & & Treatm & average & & \\
\hline $\mathbf{H}$ & & & & & & \\
\hline BRS1010 & & & & & & \\
\hline BRS1055 & & & & & & \\
\hline DKB390 & & & & & & \\
\hline WR & & & & & & \\
\hline NWS & & & & & & \\
\hline WS & & & & & & \\
\hline $\mathrm{H}^{*} \mathrm{WR}$ & & & & & & \\
\hline & NWS & WS & NWS & WS & NWS & WS \\
\hline BRS1010 & $18.06 \mathrm{abA}$ & $15.40 \mathrm{bB}$ & $41.33 \mathrm{aA}$ & $41.58 \mathrm{aA}$ & $0.33 \mathrm{aA}$ & $0.29 \mathrm{aB}$ \\
\hline BRS1055 & $18.88 \mathrm{aA}$ & $16.06 \mathrm{abB}$ & $40.66 \mathrm{aB}$ & $42.00 \mathrm{aA}$ & $0.31 \mathrm{aA}$ & $0.21 \mathrm{bB}$ \\
\hline DKB390 & $16.75 \mathrm{bA}$ & $17.75 \mathrm{aA}$ & $41.33 \mathrm{aB}$ & $42.00 \mathrm{aA}$ & $0.21 \mathrm{bA}$ & $0.21 \mathrm{bB}$ \\
\hline
\end{tabular}


continuation

Water regime (WR): no water stress (NWS) and water stress (WS). Evaluated indices: relative water content (RWC), relative chlorophyll content (RCC), leaf temperature (LT), stem length (SL), phenological stages (PHN) and shoot dry biomass (SB). Means followed by the same lowercase letter in the columns and uppercase letter in the rows (interactions) do not differ according to Tukey's test, $P<0.05\left(^{*}\right), P>0.05$ ( $\left.^{\text {ns }}\right)$.

A significant interaction effect between the genotype and water regime factors was observed for the PHN variable. By decomposing the water regime within each hybrid, we note that, under water stress, BRS1055 and DKB390 showed a slower phenological development. Phenology and the production of shoot biomass has important interactions with the acquisition of soil resources (Lynch, 2013).

Between the studied hybrids, BRS1010 had the highest SB value, as also did the plants grown in the absence of water stress (Table 1). In an experiment carried out by Clemente (2017), no significant interaction between genotypes and water regimes was detected for SB, demonstrating that the use of this trait in the selection of tolerant genotypes may not be efficient, but may greatly contribute to the identification of stress severity. Bonfim-Silva, Silva, Cabral, Kroth and Rezende (2011) evaluated maize in stages V4 and V5 and observed decreased plant dry biomass under water restriction $(30 \%$ of field capacity), which suggests that, for these hybrids, the SB index revealed low drought tolerance in its early development. According to Liu et al. (2011), one of the first responses to water deficit is closure of stomata and a reduction of the photosynthetic rate due to the decrease in $\mathrm{CO}_{2}$ capture.

\section{Root variables}

A significant interaction effect between hybrids and water regimes was seen on root dry biomass (RB), root surface area (RSA) and root volume (RV). The water regime factor influenced root length (RL) and $\mathrm{D}_{95}$. A significant difference was also observed between the hybrids for RB, RSA, RV and RL (Table 2).
Hybrid BRS1010 showed the highest RL value (Table 2). The maximum length of roots is affected not only by environmental conditions, but also by genetics (Wijewardana, Hock, Henry, \& Reddy, 2015). The work developed by M. L. Ali et al. (2016) in maize demonstrated that increased root lengths provide improved drought tolerance, which is then considered an excellent parameter to be observed when choosing genotypes tolerant to water restriction. Martins (2012) studied the tolerance of maize to drought and suggested RL as one of the best indices to differentiate tolerant strains from those sensitive to water stress. In terms of water availability, average RL was $17.96 \%$ higher in the non-stressed maize than in the plants grown under water restriction. This result corroborates the reports of Zhan and Lynch (2015), who described that water restriction significantly reduced the RL of the studied maize hybrids.

Root dry biomass differed between the hybrids and within each water regime (Table 2). In the wellirrigated treatment, hybrids BRS1010 and BRS1055 showed the highest RB. However, under water restriction, hybrid BRS1010 was superior. These findings disagree with the conclusions of Clemente (2017), who stated that the ability to produce photoassimilates is compromised when sensitive genotypes are subjected to the stress condition, which culminates in a significant reduction in DM production from both shoots and roots. Hybrid BRS1055 was the only one to show a difference between the water regimes, with a $39.45 \%$ higher $\mathrm{RB}$ in the treatment without water stress. The higher $\mathrm{RB}$ values found in the water-stress condition are possibly related to the large allocation of carbon to the roots. Nonetheless, Santos, Guimarães, Klein, Fioreze, and Macedo (2012) stated that this fact 
depends on the intensity and duration of the water deficit as well as the stage at which it occurs. This result suggests that the $\mathrm{RB}$ trait has an adaptive character, since the studied hybrid showed a difference in this variable in response to changes in the water regime.

When not subjected to water stress, hybrids BRS1010 and BRS1055 showed the largest RSA, whereas in the stress condition hybrid BRS1010 was superior. Conversely, Magalhães et al. (2015), who found higher RSA values in genotype
BRS1055 under water-stress conditions and no differences between the genotypes when stressfree. Only hybrid BRS1055 showed differences in RSA between the water regimes, with a $37.23 \%$ larger average RSA in the stress-free condition. Like root length, root surface area is also used to characterize the root system and measure its functional size (Costa et al., 2002). These traits are useful for predicting nutrient absorption capacity and performance under restricted water conditions (Wijewardana et al., 2015).

\section{Table 2}

Analysis of variance for hybrid (H), water regime (WR) and their interaction (WR * H) on root indices of maize grown under two water regimes. Janaúba - MG, Brazil, 2017

\begin{tabular}{|c|c|c|c|c|c|c|c|c|}
\hline $\begin{array}{l}\text { Source of } \\
\text { variation }\end{array}$ & \multicolumn{2}{|c|}{$\begin{array}{c}\mathbf{R L}- \\
\mathrm{cm}\end{array}$} & \multicolumn{2}{|c|}{$\begin{array}{c}\overline{\text { RDB }} \\
\mathrm{g}\end{array}$} & \multicolumn{2}{|c|}{$\begin{array}{c}\mathbf{R S A}- \\
\mathrm{cm}^{2}\end{array}$} & \multicolumn{2}{|c|}{$\begin{array}{c}\mathbf{A R D}- \\
\mathrm{mm}\end{array}$} \\
\hline & \multicolumn{8}{|c|}{ Mean squares } \\
\hline $\mathrm{H}$ & \multicolumn{2}{|c|}{$20564401.1^{*}$} & \multicolumn{2}{|c|}{$0.27 *$} & \multicolumn{2}{|c|}{$294042.69 *$} & \multicolumn{2}{|c|}{$0.01^{\mathrm{ns}}$} \\
\hline WR & \multicolumn{2}{|c|}{$3619774.8^{*}$} & \multicolumn{2}{|c|}{$0.01^{\mathrm{ns}}$} & \multicolumn{2}{|c|}{$25416.06^{\mathrm{ns}}$} & \multicolumn{2}{|c|}{$0.01^{\mathrm{ns}}$} \\
\hline $\mathrm{H}^{*} \mathrm{WR}$ & \multicolumn{2}{|c|}{$2188687.1^{\mathrm{ns}}$} & \multicolumn{2}{|c|}{$0.07 *$} & \multicolumn{2}{|c|}{$44715.36^{*}$} & \multicolumn{2}{|c|}{$0.007^{\mathrm{ns}}$} \\
\hline Mean & \multicolumn{2}{|c|}{3140.93} & \multicolumn{2}{|c|}{0.45} & \multicolumn{2}{|c|}{406.81} & \multicolumn{2}{|c|}{0.59} \\
\hline & \multicolumn{8}{|c|}{ Treatment average } \\
\hline \multicolumn{9}{|l|}{$\mathbf{H}$} \\
\hline BRS1010 & \multicolumn{2}{|c|}{$4227 \mathrm{a}$} & \multicolumn{2}{|c|}{$0.56 \mathrm{a}$} & \multicolumn{2}{|c|}{$0.56 \mathrm{a}$} & \multicolumn{2}{|c|}{$0.56 \mathrm{a}$} \\
\hline BRS1055 & \multicolumn{2}{|c|}{$3105 \mathrm{~b}$} & \multicolumn{2}{|c|}{$0.48 \mathrm{a}$} & \multicolumn{2}{|c|}{$0.48 \mathrm{a}$} & \multicolumn{2}{|c|}{$0.61 \mathrm{a}$} \\
\hline DKB390 & & & & & & & & \\
\hline WR & & & & & & & & \\
\hline NWS & & & & & & & & \\
\hline WS & & & & & & & & \\
\hline $\mathbf{H} * \mathbf{W R}$ & & & & & & & & \\
\hline & NWS & WS & NWS & WS & NWS & WS & NWS & WS \\
\hline BRS1010 & $4577 \mathrm{Aa}$ & 3877Aa & $0.59 \mathrm{aA}$ & $0.53 \mathrm{aA}$ & $571 \mathrm{aA}$ & $500 \mathrm{aA}$ & $0.57 \mathrm{Aa}$ & $0.56 \mathrm{Aa}$ \\
\hline BRS1055 & $3658 \mathrm{Aa}$ & $2552 \mathrm{Bb}$ & $0.56 \mathrm{aA}$ & $0.40 \mathrm{abB}$ & $469 \mathrm{aA}$ & $341 \mathrm{bB}$ & $0.55 \mathrm{Aa}$ & $0.61 \mathrm{Aa}$ \\
\hline DKB390 & $1964 \mathrm{Ba}$ & $2217 \mathrm{Ba}$ & $0.27 \mathrm{bA}$ & $0.37 \mathrm{bA}$ & $247 \mathrm{bA}$ & $314 \mathrm{bA}$ & $0.59 \mathrm{Aa}$ & $0.64 \mathrm{Aa}$ \\
\hline $\begin{array}{l}\text { Source of } \\
\text { variation }\end{array}$ & -1 & $y-$ & -1 & 5 & - & - & & \\
\hline & & & & Mean & uares & & & \\
\hline $\mathrm{H}$ & & & & & & & & \\
\hline WR & & & & & & & & \\
\hline $\mathrm{H}^{*} \mathrm{WR}$ & & & 13 & $9^{\text {ns }}$ & & & & \\
\hline Mean & & & & & & & & \\
\hline
\end{tabular}


continuation

\section{Treatment average}

H

\begin{tabular}{|c|c|c|c|c|c|c|}
\hline BRS1010 & \multicolumn{2}{|c|}{$5.52^{\mathrm{a}}$} & \multicolumn{2}{|c|}{$64.48 \mathrm{a}$} & \multicolumn{2}{|c|}{$2.05 \mathrm{a}$} \\
\hline BRS1055 & \multicolumn{2}{|c|}{$4.33 b$} & \multicolumn{2}{|c|}{$62.70 \mathrm{a}$} & \multicolumn{2}{|c|}{$2.62 \mathrm{a}$} \\
\hline DKB390 & \multicolumn{2}{|c|}{$3.07 \mathrm{c}$} & \multicolumn{2}{|c|}{$61.42 \mathrm{a}$} & \multicolumn{2}{|c|}{$1.87 \mathrm{a}$} \\
\hline \multicolumn{7}{|l|}{ WR } \\
\hline NWS & \multicolumn{2}{|c|}{$4.40 \mathrm{a}$} & \multicolumn{2}{|c|}{$60.30 \mathrm{~b}$} & \multicolumn{2}{|c|}{$1.83 \mathrm{a}$} \\
\hline WS & \multicolumn{2}{|c|}{$4.20 \mathrm{a}$} & \multicolumn{2}{|c|}{$65.44 \mathrm{a}$} & \multicolumn{2}{|c|}{$2.18 \mathrm{a}$} \\
\hline \multicolumn{7}{|l|}{ H*WR } \\
\hline & NWS & WS & NWS & WS & NWS & WS \\
\hline BRS1010 & $5.79 \mathrm{aA}$ & $5.24 \mathrm{aA}$ & $64.19 \mathrm{Ab}$ & $68.26 \mathrm{Aa}$ & $1.78 \mathrm{Aa}$ & $2.05 \mathrm{Aa}$ \\
\hline BRS1055 & $4.90 \mathrm{aA}$ & $3.75 \mathrm{bA}$ & $59.56 \mathrm{Aa}$ & $64.78 \mathrm{Aa}$ & $2.14 \mathrm{Aa}$ & $2.62 \mathrm{Aa}$ \\
\hline DKB390 & $2.52 \mathrm{bA}$ & $3.61 \mathrm{bA}$ & $57.15 \mathrm{Aa}$ & $63.27 \mathrm{Aa}$ & $1.64 \mathrm{Aa}$ & $1.87 \mathrm{Aa}$ \\
\hline
\end{tabular}

Water regime (WR): no water stress (NWS) and with stress (WS). Evaluated indices: root length (RL), root dry biomass (RDB), root surface area (RSA), average root diameter (ARD), root volume (RV), depth above which $95 \%$ of the roots were located in the tube $\left(\mathrm{D}_{95}\right)$ and root/shoot dry biomass ratio $(\mathrm{R} / \mathrm{S})$. Means followed by the same lowercase letter in the columns and uppercase letter in the rows (interactions) do not differ according to Tukey's test $P<0.05$ (*), $P>0.05$ (ns).

Average root diameter was not influenced by the sources of variation tested in this study, which indicates that it is a non-responsive trait. The present results do not agree with those reported by Cantão, Durães, Oliveira, Soares and Magalhães (2008), who found a higher proportion of roots less than 0.5 $\mathrm{mm}$ in diameter in their study with drought-tolerant maize lines.

Root volume differed significantly between the hybrids within each water regime (Table 2). In the stress-free condition, hybrids BRS1010 and BRS1055 showed the largest RV, whereas in the water-stress condition BRS1010 was superior for this trait.

The plants under water stress showed a $\mathrm{D}_{95}$ of $65.44 \mathrm{~cm}$, versus $60.03 \mathrm{~cm}$ measured in the irrigated maize. This means that, regardless of genotype, plants under water restriction explore an $8.52 \%$ greater depth in the soil profile in relation to those kept in restricted conditions (Table 2). A study carried out by Fan, McConkey, Wang and Janzen (2016) reported that the soil region of greatest distribution of maize roots as estimated by $\mathrm{D}_{95}$ is between 50 $100 \mathrm{~cm}$, which is in line with the results obtained in the present study. As stated by Monshausen and Gilroy (2009), the roots of plants of different species are able to detect moisture gradients and adjust their growth via soil exploration when more water is available, through a phenomenon called hydrotropism (Loomis \& Ewan, 1936). However, Cole and Mahall (2006) did not observe root growth towards areas with water availability even in soil with very marked moisture gradients, which suggests that the variable in question would not be an appropriate index to distinguish genotypes regarding tolerance to water deficits.

Neither RB/SB ratio nor ARD were influenced by the treatment factors tested in this study. For the plants grown with and without water stress, the mean $\mathrm{RB} / \mathrm{SB}$ ratios were 2.18 and 1.83 , respectively.

Relative chlorophyll content, LT, SL, SB, $\mathrm{RL}, \mathrm{RB}, \mathrm{RSA}$ and $\mathrm{D}_{95}$ responded significantly to water stress, whereas ARD, RV, RB/SB and RWC remained unchanged regardless of the water regime. 
Multivariate analysis of variance (MANOVA) isolation when analyzed in a multivariate manner was not significant $(\mathrm{p}<0.05)$ for the hybrid $\times$ water $\quad$ (Table 3$)$.

regime interaction, indicating that the factors act in

Table 3

Multivariate analysis of variance for quantitative traits evaluated in maize hybrids grown in two water regimes. Janaúba-MG, Brazil, 2017

\begin{tabular}{cccc}
\hline Source of variation & DF & Pillai & p-value \\
\hline Hybrid $(\mathrm{H})$ & 2 & 1.4591 & $3.46 \mathrm{E}-5^{*}$ \\
Water regime $(\mathrm{WR})$ & 1 & 0.9505 & $3.57 \mathrm{E}-10^{*}$ \\
Block & 2 & 1.3073 & $1.75 \mathrm{E}-3^{*}$ \\
H $^{*} \mathrm{WR}$ & 2 & 0.9931 & $1.72 \mathrm{E}-1^{\mathrm{ns}}$ \\
\hline
\end{tabular}

$P<0.05(*), P>0.05\left(^{\text {ns }}\right)$. DF: degrees of freedom. Pillai: estimate by Pillai's test.

The first two canonical variables (CV) explained $81.46 \%$ of the observed variation, allowing us to satisfactorily distinguish the difference between treatments using a two-dimensional scatterplot, where four distinct groups were formed (Figure 1). The first group was formed by hybrids BRS1010 and BRS1055, without water stress. The second group, also without water stress, was composed of hybrid DKB390. The third group was formed by DKB390 and BRS1055 under water stress; and the last group consisted of hybrid BRS1010 also under water stress.

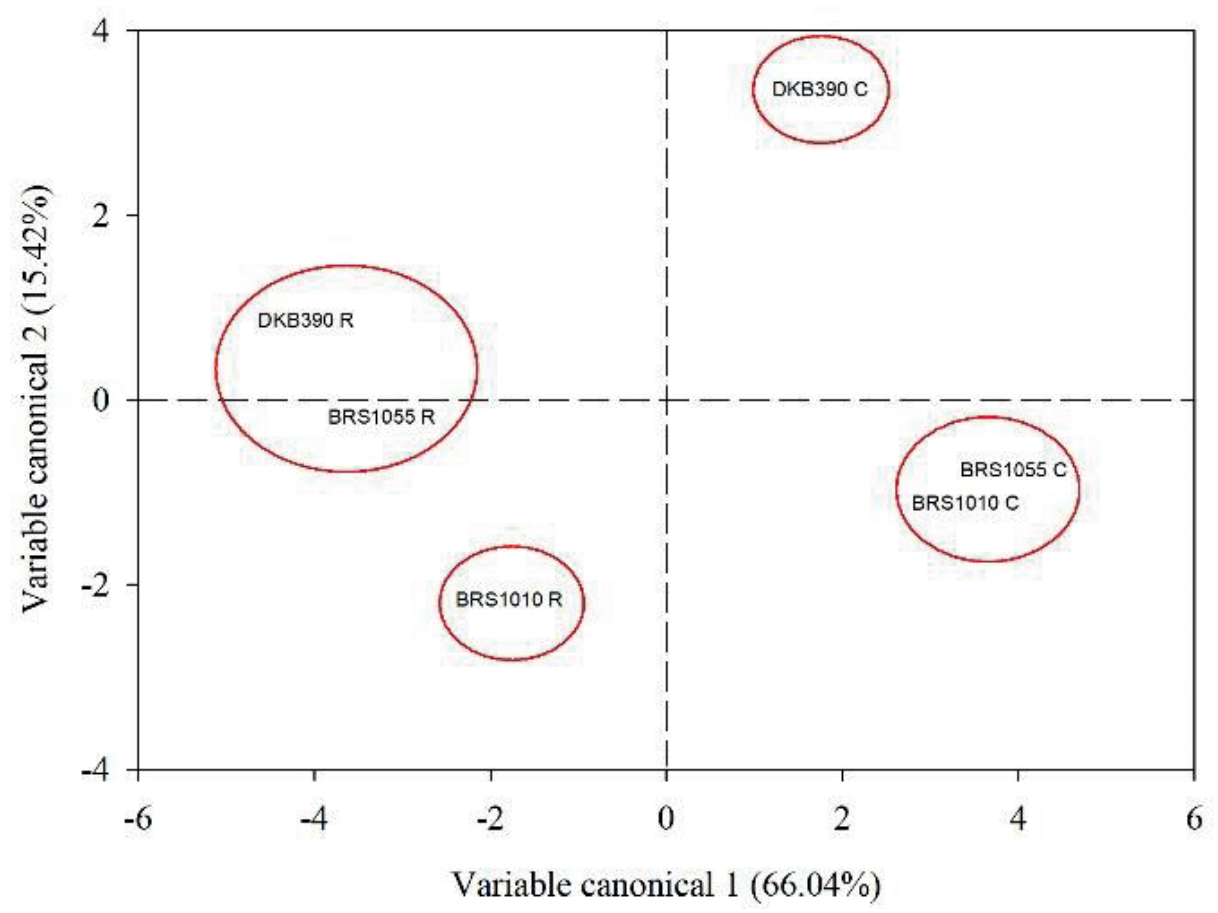

Figure 1. Standardized canonical scores for canonical variables CV1 and CV2, presented in a two-dimensional form, considering three maize hybrids and two water regimes. Janaúba-MG, Brazil, 2017. 
Canonical variable 1 (CV1) explained 66.04\% of the obtained variation, and the traits that most contributed to it were RCC, PHN, LT and the ARD (Table 4). Considering the high negative correlation of these variables with CV1, the scatterplot indicates that, when subjected to water stress, all genotypes presented higher values for SPAD, LT and ARD and the most delayed phenological development, since they are positioned in the negative (left) quadrant of the CV1 axis. Sousa, Bastos, Cardoso and Pereira (2018) examined the application of multivariate analysis in the study of water deficit in maize and stated that several relevant traits can be included in the selection of drought-tolerant genotypes, e.g., chlorophyll content, leaf temperature, plant growth analysis and root depth and volume. These traits may be correlated with crop yield (F. Ali, Ahsan, Ali, \& Kanwal, 2017).

Table 4

Canonical correlations referring to canonical scores for 13 quantitative traits evaluated in commercial maize hybrids grown under two water regimes Janaúba-MG, Brazil, 2017

\begin{tabular}{lcc}
\hline \multirow{2}{*}{ Quantitative trait } & \multicolumn{2}{c}{ Canonical variable (CV) } \\
\cline { 2 - 3 } Relative chlorophyll content (RCC) & CV1 & CV2 \\
Stem length & -0.98 & -0.18 \\
Relative water content & 0.41 & 0.32 \\
Shoot dry biomass & 0.10 & 0.64 \\
Leaf temperature & 0.68 & -0.62 \\
V5 phenology & -0.84 & -0.14 \\
D95 & -0.93 & 0.01 \\
Root dry biomass & -0.54 & -0.46 \\
Root length & 0.41 & -0.89 \\
Root surface area & 0.51 & -0.82 \\
Root volume & 0.43 & -0.86 \\
Average root diameter & 0.34 & -0.91 \\
Root/shoot ratio & -0.75 & 0.44 \\
\hline
\end{tabular}

The second canonical variable (CV2) explained $15.42 \%$ of the variation between the treatments, and the most relevant traits were RB, RL, RSA, RV and RB/SB. Bibi, Sadaqat, Tahir and Akram (2012) investigated water stress in sorghum and found, using multivariate analysis that, associated with a lower leaf water potential, greater root and shoot lengths can be used as selection criteria for tolerance to drought in sorghum in the vegetative phase. In the present study, the means of the traits evaluated in the hybrids sensitive to water stress were also better than in the tolerant hybrids, agreeing with the above-mentioned authors.

\section{Conclusions}

Relative chlorophyll content, leaf temperature, stem length, shoot dry biomass, root length, root dry biomass, root surface area and $\mathrm{D}_{95}$ are indices responsive to water deficit, in contrast to average root diameter, root volume, root/shoot ratio and relative leaf water content. The indices that best explain the difference between hybrids in the evaluated water regimes were relative chlorophyll content, leaf temperature, phenology and average root diameter. 


\section{Acknowledgments}

The authors thank the National Maize and Sorghum Research Center - Brazilian Agricultural Research Corporation (CNPMS-EMBRAPA).

\section{References}

Abendroth, L. J., Elmore, R. W., Boyer, M. J., \& Marlay, S. K. (2011). Corn growth and development (PMR 1009). Ames: Iowa State University Extension.

Adebo, F., \& Olaoye, G. (2015). Growth indices and grain yield attributes in six maize cultivars representing two era of maize breeding in Nigeria. Journal of Agricultural Research and Development, 14(2), 1125. doi: $10.5539 /$ jas.v2n3p218

Ali, F., Ahsan, M., Ali, Q., \& Kanwal, N. (2017). Phenotypic stability of Zea mays grain yield and its attributing traits under drought stress. Frontiers in Plant Science, (8), 1397. doi: 10.3389/ fpls.2017.01397

Ali, M. L., Luetchens, J., Singh, A., Shaver, T. M., Kruger, G. R., \& Lorenz, A. J. (2016). Greenhouse screening of maize genotypes for deep root mass and related root traits and their association with grain yield under water-deficit conditions in the field. Euphytica, 207(1), 79-94. doi: 10.1007/s10681-0151533-X

Araus, J. L., Serret, M. D., \& Edmeades, G. (2012). Phenotyping maize for adaptation to drought. Frontiers in Physiology, (3), 1-20. doi: 10.3389/ fphys.2012.00305

Beiragi, M. A., Ebrahimi, M., Mostafavi, K., Golbashy, M., \& Khorasani, S. K. (2011). A study of morphological basis of corn (Zea mays L.) yield under drought stress condition using correlation and path coefficient analysis. Journal of Cereals and Oilseeds, 2(2), 32-37.

Bengough, A. G., McKenzie, B., Hallett, P., \& Valentine, T. (2011). Root elongation, water stress, and mechanical impedance: a review of limiting stresses and beneficial root tip traits. Journal of Experimental Botany, 62(1), 59-68. doi: 10.1093/jxb/erq350

Bergamaschi, H., \& Matzenauer, R. (2014). O milho e o clima. Porto Alegre: Emater/RS-Ascar.

Bibi, A., Sadaqat, H., Tahir, M., \& Akram, H. (2012). Screening of sorghum (Sorghum bicolor var Moench) for drought tolerance at seedling stage in polyethylene glycol. The Journal of Animal \& Plant Sciences, 22(3), 671-678.

Bonfim-Silva, E. M., Silva, T. J. A. da, Cabral, C. E. A., Kroth, B. E., \& Rezende, D. (2011). Desenvolvimento inicial de gramíneas submetidas ao estresse hídrico. Revista Caatinga, 24(2), 180-186.

Burton, A. L., Brown, K. M., \& Lynch, J. P. (2013). Phenotypic diversity of root anatomical and architectural traits in Zea species. Crop Science, 53(3), 1042-1055. doi: 10.2135/cropsci2012.07.0440

Cantão, F. R. D. O., Durães, F. O. M., Oliveira, A. C. de, Soares, Â. M., \& Magalhães, P. C. (2008). Morphological attributes of root system of maize genotypes contrasting in drought tolerance due to phosphorus stress. Revista Brasileira de Milho e Sorgo, 7(2), 113-127.

Clemente, D. I. (2017). Estresse hídrico sobre caracteres morfofisiológicos e agronômicos em populações de milho. Dissertação de mestrado, Universidade Federal de Goiás, Jataí, GO, Brasil.

Cole, E. S., \& Mahall, B. E. (2006). A test for hydrotropic behavior by roots of two coastal dune shrubs. New Phytologist, 172(2), 358-368. doi: 10.1111/j.14698137.2006.01822.x

Cooper, M., Gho, C., Leafgren, R., Tang, T., \& Messina, C. (2014). Breeding drought-tolerant maize hybrids for the US corn-belt: Discovery to product. Journal of Experimental Botany, 65(21), 6191-6204. doi: $10.1093 / \mathrm{jxb} / \mathrm{eru} 064$

Costa, C., Dwyer, L. M., Zhou, X., Dutilleul, P., Hamel, C., Reid, L. M., \& Smith, D. L. (2002). Root morphology of contrasting maize genotypes. Agronomy Journal, 94(1), 96-101. doi: 10.2134/ agronj2002.9600

Fan, J., McConkey, B., Wang, H., \& Janzen, H. (2016). Root distribution by depth for temperate agricultural crops. Field Crops Research, (189), 68-74. doi: 10.1016/j.fcr.2016.02.013

Fonseca, T. M., \& Magalhães, P. C. (2017). Interferência do déficit hídrico na produtividade e acúmulo de sólidos solúveis em genótipos de milho contrastantes a seca. Anais do Seminário de Iniciação Científica PIBIC/BIC JÚNIOR, Sete Lagoas, MG: EMBRAPA Milho e Sorgo.

Friendly, M., \& Fox, J. (2017). Candisc: visualizing generalized canonical discriminant and canonical correlation analysis (Version $\mathrm{R}$ package version 0.6-5). Retrieved from http://CRAN.R-project.org/ package $=$ candisc 
Iwuala, E., Odjegba, V., Umebese, C., Sharma, V., \& Alam, A. (2019). Physiological and gene expression studies of selected Zea mays L. and Pennisetum glaucum (L.) R. Br. Genotypes to simulated drought stress condition. Vegetos, 32(3), 397-406. doi: $10.1007 / \mathrm{s} 42535-019-00030-7$

Kamoshita, A., Rodriguez, R., Yamauchi, A., \& Wade, L. (2004). Genotypic variation in response of rainfed lowland rice to prolonged drought and rewatering. Plant Production Science, 7(4), 406-420. doi: 10.1626/pps.7.406

Kappes, C., Carvalho, M. A. C., Yamashita, O. M., \& Silva, J. A. da, Neto. (2009). Influência do nitrogênio no desempenho produtivo do milho cultivado na segunda safra em sucessão à soja. Pesquisa Agropecuária Tropical, 39(3), 251-259. doi: Recuperado de https://www.redalyc.org/articulo. oa? id= 2530/253020158009

Lavinsky, A. O., Magalhães, P. C., Ávila, R. G., Diniz, M. M., \& Souza, T. C. de. (2015). Partitioning between primary and secondary metabolism of carbon allocated to roots in four maize genotypes under water deficit and its effects on productivity. The Crop Journal, 3(5), 379-386. doi: 10.1016/j. cj.2015.04.008

Liu, Y., Subhash, C., Yan, J., Song, C., Zhao, J., \& Li, J. (2011). Maize leaf temperature responses to drought: Thermal imaging and quantitative trait loci (QTL) mapping. Environmental and Experimental Botany, 71(2), 158-165. doi: 10.1016/j. envexpbot.2010.11.010

Loomis, W., \& Ewan, L. (1936). Hydrotropic responses of roots in soil. Botanical Gazette, 97(4), 728-743.

Lynch, J. P. (2013). Steep, cheap and deep: an ideotype to optimize water and $\mathrm{N}$ acquisition by maize root systems. Annals of Botany, 112(2), 347-357. doi: $10.1093 / \mathrm{aob} / \mathrm{mcs} 293$

Magalhães, P. C., Lavinsky, A., Avila, R., Alves, J., Melo, M., Gomes, C., Jr., \& Melo, H. (2015). Caracterização do sistema radicular e dos componentes da produtividade em quatro genótipos de milho cultivados sob déficit hídrico. (INFOTECA-E).

Magalhães, P. C., Souza, T. C. de, \& Albuquerque, P. E. P. de. (2012). Efeitos do estresse hídrico na produção de grãos e na fisiologia da planta de milho. Sete Lagoas: EMBRAPA Milho e Sorgo. Recuperado de http://ainfo.cnptia.embrapa.br/digital/bitstream/ item/72403/1/bol-51.pdf
Magalhães, P. C., Souza, T. C. de, Albuquerque, P. E. P. de, Karam, D., Magalhães, M. M., \& Cantão, F. R. D. O. (2009). Caracterização ecofisiológica de linhagens de milho submetidas a baixa disponibilidade hídrica durante o florescimento. Revista Brasileira de Milho e Sorgo, 8(3), 223-232. doi: 10.18512/1980-6477/ rbms.v8n3p223-232

Martins, A. O. (2012) Inferências genético-fisiológicas da tolerância à seca em milho. Tese de doutorado, Universidade Estadual do Norte Fluminense Darcy Ribeiro, Campos dos Goytacazes, RJ, Brasil.

Monshausen, G. B., \& Gilroy, S. (2009). The exploring root Root growth responses to local environmental conditions. Current Opinion in Plant Biology, 12(6), 766-772. doi: 10.1016/j.pbi.2009.08.002

Mutava, R., Prasad, P., Tuinstra, M., Kofoid, K., \& Yu, J. (2011). Characterization of sorghum genotypes for traits related to drought tolerance. Field Crops Research, 123(1), 10-18. doi: 10.1016/j. fcr.2011.04.006

R Core Team (2016). R: A Language and environment for statistical computing. R Foundation for Statistical Computing. Retrieved from https://www.R-project. org/

Rufino, C. de A., Tavares, L. C., Vieira, J., Dörr, C., Villela, F., \& Barros, A. (2012). Desempenho de genótipos de milho submetidos ao déficit hídrico no estádio vegetativo. Magistra, 24(3), 217-225.

Santos, D., Guimarães, V. F., Klein, J., Fioreze, S. L., \& Macedo Jr., E. K. (2012). Cultivares de trigo submetidas a déficit hídrico no início do florescimento, em casa de vegetação. Revista Brasileira de Engenharia Agrícola e Ambiental, 16(8), 836-842. doi: 10.1590/S1415-43662012000800004

Schenk, H. J., \& Jackson, R. B. (2002). The global biogeography of roots. Ecological Monographs, 72(3), 311-328. doi: 10.1890/0012-9615(2002)072[0311:TGBOR]2.0. $\mathrm{CO} ; 2$

Sousa, R. S. de, Bastos, E. A., Cardoso, M. J., \& Pereira, D. R. (2018). Identification of drought-tolerant corn genotypes by multivariate analysis. Pesquisa Agropecuária Tropical, 48(3), 204-211. doi: $10.1590 / 1983-40632018 v 4852122$

Teixeira, F. F., Gomide, R. L., Albuquerque, P. E. P. de, Andrade, C. L. T. de, Leite, C. E. P., Parentoni, S. N.,... Bastos, E. A. (2010). Evaluation of maize core collection for drought tolerance. Crop Breeding and Applied Biotechnology, 10(4), 312-320. doi: 10.1590/S1984-70332010000400005 
Weatherley, P. E. (1950). Studies in the water relations of cotton plants. I. The field measurement of water deficit in leaves. New Phytologist, (49), 81-87. doi: 10.1111/j.1469-8137.1950.tb05146.x

Wijewardana, C., Hock, M., Henry, B., \& Reddy, K. R. (2015). Screening corn hybrids for cold tolerance using morphological traits for early-season seeding. Crop Science, 55(2), 851-867. doi: 10.2134/csa201560-3-2
Zhan, A., \& Lynch, J. P. (2015). Reduced frequency of lateral root branching improves $\mathrm{N}$ capture from low-N soils in maize. Journal of Experimental Botany, 66(7), 2055-2065. doi: 10.1093/jxb/erv007

Zhu, J., Brown, K. M., \& Lynch, J. P. (2010). Root cortical aerenchyma improves the drought tolerance of maize (Zea mays L.). Plant, Cell \& Environment, 33(5), 740-749. doi: 10.1111/j.1365-3040.2009.02099.x 